\title{
Complete Genome Sequence of Proteus mirabilis Phage PPM_01 Isolated from Raw Sewage
}

\author{
Ira Aryani Wirjon ${ }^{\mathrm{a}} \mathrm{b}$ Nyok-Sean Lau ${ }^{\mathrm{b}}$ Yahya Mat Arip ${ }^{\mathrm{a}}$

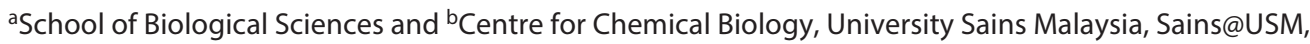 \\ Bayan Lepas, Penang, Malaysia
}

\section{Keywords}

Proteus mirabilis · Lytic phage pPM_01 - Genome · Urinary tract infection

\begin{abstract}
Objectives: Phage pPM_01 was previously isolated from a raw sewage treatment facility located in Batu Maung, Penang, Malaysia, and it was highly lytic against Proteus mirabilis, which causes urinary tract infections in humans. In this paper, we characterize the biology and complete genome sequence of the phage. Methods and Results: Transmission electron microscopy revealed phage PPM_01 to be a siphovirus (the first reported virus to infect $P$. mirabilis), with its complete genome sequence successfully determined. The genome was sequenced using Illumina technology and the reads obtained were assembled using CLC Genomic Workbench v.7.0.3. The whole genome contains a total of 58,546 bp of linear double-stranded DNA with a G+C content of $46.9 \%$. Seventy putative genes were identified and annotated using various bioinformatics tools including RAST, Geneious v.R7, National Center for Biotechnology Information (NCBI) BLAST, and tRNAscan-SE-v1.3 Search. Functional clusters of related potential genes were defined (structural, lytic,
\end{abstract}

\section{KARGER}

E-Mail karger@karger.com

www.karger.com/int packaging, replication, modification, and modulatory). The whole genome sequence showed a low similarity to known phages (i.e., Enterobacter phage Enc34 and Enterobacteria phage $\mathrm{Chi}$.) Host range determination and SDS-PAGE analysis were also performed. Conclusions: The inability to lysogenize a host, the absence of endotoxin genes in the annotated genome, and the lytic behavior suggest phage PPM_01 as a possible safe biological candidate to control $P$. mirabilis infection.

(c) 2017 S. Karger AG, Basel

\section{Introduction}

Bacterial viruses or phages belong to a group of viruses that specifically infect bacterial cells and utilize them as hosts to propagate [1]. Phages are environmentally ubiquitous, with an estimated $10^{31}$ particles on earth $[1,2]$. Metagenomic analyses have revealed that they are immensely diverse and present in almost all niches where bacterial cells are present $[3,4]$. Phages have the capability to kill specific bacteria during exponential bacterial growth. This is a desirable trait in phage therapy, which is one of the treatments for bacterial infectious diseases. (c) 2017 S. Karger AG, Basel

$0300-5526 / 17 / 0596-0243 \$ 39.50 / 0$
Dr. Yahya Mat Arip

School of Biological Sciences University Sains Malaysia

Bayan Lepas, Penang 11800 (Malaysia)

E-Mail ymarip@usm.my 
Phage therapy involves the employment of phages or their products as biological control agents against diseases initiated by pathogenic bacteria [5]. The Republic of Georgia has employed phage therapy primarily for standard medical practices, and phages have been routinely used in many hospitals and clinics $[1,6]$. The Southwest Regional Wound Care Centre (Lubbock, TX, USA) has applied phages in conjunction with other methods to treat venous leg ulcers instigated by multidrug-resistant Pseudomonas. The antibiotic treatments proved to be unsuccessful in promoting recovery for more than a year even though conservative wound care practices were implemented. However, when treated with phage therapy, the infected wound responded rapidly to form healthy skin [7].

According to the International Committee on Taxonomy of Virus, most phages used in phage therapy belong to the order Caudovirales. These phages are tailed phages and could be further classified into the Myoviridae, Siphoviridae, or Podoviridae families [8,9]. Two types of phages are found in nature according to their life cycle: virulent (lytic) and temperate (lysogenic). Generally, only lytic phages are qualified for therapeutic purposes [10]. Lytic phages destroy or kill their host cells, while temperate phages infect the host cell and directly incorporate its genome into the host genome (prophage) or exist as an episomal element in the bacteria [11]. The lysogenic cycle would eventually lead to a permanent association between the prophage and the host cell, as well as all the progenies [12]. The host cells that harbor these prophages are termed lysogenic bacteria. Prophage plays an important role in the introduction of gene clusters, which contributes to pathogen virulence. Temperate phages encoding a virulence gene or a potential toxin could convert the bacterial host from a nonpathogenic strain to a pathogenic strain or to a strain with increased virulence [13]. Due to a different replication pathway, infection by a temperate phage would not necessarily end with the formation of plaques, despite the ability of a temperate phage to perform the lytic cycle. Additionally, this type of phage is seldom utilized in phage typing, which is another phagerelated application used in hospitals to define the origin and course of diseases including nosocomial infection [14]. Phage typing specifies which phage a bacterium is susceptible to and it is frequently applied to identify methicillin-resistant Staphylococcus aureus (MRSA), Pseudomonas aeruginosa, Salmonella typhi, and others [15].

P. mirabilis is a highly motile bacterium that belongs to the Enterobacteriaceae family [16-18]. This bacterium is part of the human gastrointestinal tract microflora, as well as an opportunistic pathogen that could harm the host. In an immunocompromised human, $P$. mirabilis has the potential to evoke infections in various parts of the body [19]. The Proteus species is considered one of the uropathogens in humans and it is also the most common species reported in hospital patients associated with urolithiasis or indwelling urinary catheters $(\sim 80 \%$ of infections) [20-24]. As a matter of fact, $P$. mirabilis is commonly isolated from the biofilms that are formed on urinary catheters [16, 18]. Compared to Escherichia coli infections, reports of urinary tract infections (UTI) involving $P$. mirabilis are fewer. However, $P$. mirabilis infections are likely to be chronic and relatively persistent, as well as difficult to cure. They could lead to serious complications, threatening the health of patients compared to those infected by $E$. coli $[19,20]$. The $P$. mirabilis strain has been demonstrated to be resistant to various antibiotics $[23,25]$ and it has produced extended-spectrum class A ß-lactamases [25]. Recently, the mortality rate due to antibiotic resistance of pathogenic bacteria has increased to 25,000 people per year in the USA and Europe [26]. The rise of multidrug-resistant bacteria poses serious public health and socioeconomic risks [27].

A promising alternative to antibiotics is the use of phage therapy. In this study, we present the biological characterization and complete genetic components of a lytic P. mirabilis phage designated pPM_01. To our knowledge, this is the first report of a complete genome sequence analysis for a lytic Siphovoridae phage infecting $P$. mirabilis. In addition, phage PPM_01 is free from any virulent or toxic genes and is hence classified as a potentially safe biological agent against diseases caused by $P$. mirabilis.

\section{Materials and Methods}

Bacterial Strains and Culture Media

The bacterial strains used in this study and their sources are listed in Table 1. P. mirabilis was used as a primary host for isolation, propagation, and characterization of phage pPM_01. The strain used was a clinical isolate obtained from the Microbiology Collections, School of Biological Sciences, Universiti Sains Malaysia. The bacterium was propagated at $37^{\circ} \mathrm{C}$ in lysogeny broth (LB) medium.

Agar Layer (Overlay) Method

The overlay method was performed according to the standard protocols of Adams [28] and Carey-Smith et al. [29] with minor modifications. To prepare the LB (Oxoid, UK) base plates, agar at a concentration of $1.5 \%$ was used while soft agar overlays were prepared at $0.5 \%$. Exponential phase host culture $\left(\mathrm{OD}_{600} \sim 0.5\right)$ and
244

Intervirology 2016;59:243-253 DOI: $10.1159 / 000468987$
Wirjon/Lau/Arip 
Table 1. Bacterial strains used and their susceptibility to phage pPM_01

\begin{tabular}{|c|c|}
\hline Bacterial strain & Susceptibility \\
\hline Escherichia coli ATCC $13706^{\mathrm{a}}$ & - \\
\hline Escherichia coli ATCC $11303^{\mathrm{a}}$ & - \\
\hline Escherichia coli $\mathrm{O} 157: \mathrm{H}^{\mathrm{b}}$ & - \\
\hline Proteus mirabilis ${ }^{\mathrm{c}}$ & + \\
\hline Pseudomonas aeruginosa ${ }^{\mathrm{c}}$ & - \\
\hline Klebsiella sp. ${ }^{c}$ & - \\
\hline Enterobacter sp. ${ }^{\mathrm{c}}$ & - \\
\hline Salmonella sp. ${ }^{\mathrm{c}}$ & - \\
\hline Bacillus subtilis ${ }^{c}$ & - \\
\hline Micrococcus sp. ${ }^{\mathrm{c}}$ & - \\
\hline
\end{tabular}

+, lysis; -, no lysis. ${ }^{\text {a }}$ Purchased from the American Type Culture Collection (ATCC). ${ }^{\mathrm{b}}$ Purchased from the National Public Health Laboratory, Ministry of Health, Malaysia. ${ }^{c}$ Obtained from the Microbiology Collections, School of Biological Sciences, Universiti Sains Malaysia.

phage were added to the base plate. A volume of $3 \mathrm{~mL}$ of soft agar $\left(45^{\circ} \mathrm{C}\right)$ was poured onto each base plate, which was swirled several times to properly mix and spread the mixture into a uniform top layer. The plate was incubated at $37^{\circ} \mathrm{C}$ for $24 \mathrm{~h}$, after which plaque (clear zone) formation in the bacterial lawn was observed.

\section{Sewage Sample Collection and Treatment}

The sample was collected from a raw sewage facility treatment located in Batu Maung, Penang, Malaysia (GPS: $5.2833^{\circ} \mathrm{N}$, $\left.100.2833^{\circ} \mathrm{E}\right)$. The samples were transported to the laboratory at ambient temperature $\left(\sim 30^{\circ} \mathrm{C}\right)$, stored at $4^{\circ} \mathrm{C}$, and processed within $24 \mathrm{~h}$. The raw sewage sample was passed through filter paper (Whatman No. 1) to remove cellular materials and solid particles. The filtrate was then immediately used for phage isolation.

\section{Phage Isolation}

Ten milliliter of overnight $P$. mirabilis culture $\left(\sim 10^{8} \mathrm{CFU} / \mathrm{mL}\right)$ was mixed with an equal amount of filtrate. The mixture was incubated by shaking at $37^{\circ} \mathrm{C}$ overnight. Following the incubation, the bacteria cells were removed by centrifugation at $12,000 \mathrm{~g}$ for 10 $\min$ at $4^{\circ} \mathrm{C}$ and the supernatant was filtered using a sterile syringe filter with a pore size of $0.45 \mu \mathrm{m}$ (Sartorius AG, Germany). The presence of an infectious phage was screened using the standard agar layer method $[28,29]$. Subsequently, $100 \mu \mathrm{L}$ of the filtrate, 100 $\mu \mathrm{L}$ of the bacterial culture $\left(\mathrm{OD}_{600} \sim 0.6\right)$, and the overlay agar were poured on the base plate. Plaques were identified after an overnight incubation at $37^{\circ} \mathrm{C}$.

\section{Phage Purification and Titration}

A single plaque on the bacterial lawn was purified using 3 consecutive single-plaque isolations to obtain a pure phage stock [30]. The overlay method was performed to check the consistency of the plaque morphologies $[28,29]$. After an overnight incubation, $5 \mathrm{~mL}$ of the SM buffer was added to the plate and left at room temperature for $2 \mathrm{~h}$ to elute the phage. The SM buffer was removed and centrifuged at 4,500 $\mathrm{g}$ for $15 \mathrm{~min}$, which was sufficient to decant any remaining agar. The supernatant was filtered using a $0.45-\mu \mathrm{m}$ syringe filter (Sartorius AG, Germany) and ultracentrifuged (Beckman Coulter, US) for $2 \mathrm{~h}$ at $100,000 \mathrm{~g}$ at a temperature of $4^{\circ} \mathrm{C}$ to concentrate the phage. The supernatant was discarded, and $200 \mu \mathrm{L}$ SM buffer was then added. The pellet was resuspended gently, and the phage titer was determined via the overlay method [28,29].

\section{Phage Propagation}

The propagation of phage pPM_01 was performed based on a modified protocol of Sambrook and Russell [31] using P. mirabilis as a host. Briefly, a single colony of bacteria on the LB agar plate was grown in $10 \mathrm{~mL}$ of $\mathrm{LB}(10.0 \mathrm{~g} / \mathrm{L} \mathrm{NaCl}, 10.0 \mathrm{~g} / \mathrm{L}$ tryptone, and $5.0 \mathrm{~g} / \mathrm{L}$ yeast extract) and incubated on an orbital shaker at $180 \mathrm{rpm}$ and $37^{\circ} \mathrm{C}$ for $3-5 \mathrm{~h}\left(\mathrm{OD}_{600} \sim 0.6 ; \sim 10^{8} \mathrm{CFU} / \mathrm{mL}\right)$ [32]. The phage stock $\left(10^{10} \mathrm{PFU} / \mathrm{mL}\right)$ was mixed with the cultured host at a multiplicity of infection of 1 and incubated again overnight. The infected culture was centrifuged at $12,000 \mathrm{~g}$ for $20 \mathrm{~min}$ at $4^{\circ} \mathrm{C}$, and the collected supernatant was filter sterilized using $0.45-\mu \mathrm{m}$ syringe filters. Chloroform $(1 \% \mathrm{v} / \mathrm{v})$ was added into the phage stock and kept at a temperature of $4^{\circ} \mathrm{C}$.

\section{Transmission Electron Microscopy}

A drop of the phage stock containing a high titer of $10^{10} \mathrm{PFU} /$ $\mathrm{mL}$ was spotted onto a film-coated carbon grid for $3 \mathrm{~min}[33,34]$. One drop of the negative stain solution ( $2 \%$ methylamine tungstate, $\mathrm{pH}$ 6.5) was instantaneously dropped on the surface of the film-coated carbon grid and visualized using TEM (Philips CM12 equipped with an analysis system; Philips Electron Optics) at the Microscopy Unit, School of Biological Sciences, Universiti Sains Malaysia.

\section{Host Range Analysis}

Phage specificity was examined using a spot test assay against several bacterial strains (Table 1) on LB agar plates as described by Jun et al. [35], with modifications. In each test, a volume of $100 \mu \mathrm{L}$ $\left(\mathrm{OD}_{600} \sim 0.5\right)$ of bacteria culture and $3 \mathrm{~mL}$ of molten soft agar were added to the base plate. Subsequently, the plate containing the mixtures was swirled and left to solidify for $30 \mathrm{~min}$. After that, 10 $\mu \mathrm{L}$ of the phage stock $\left(10^{10} \mathrm{PFU} / \mathrm{mL}\right)$ was used to spot a bacterial lawn on a plate and the absorption was left for $30 \mathrm{~min}$. The lytic activities of the isolated phage were inspected following an overnight incubation at $37^{\circ} \mathrm{C}$ and the plaque formations were differentiated on a scale as follows: + (lysis) and - (no lysis). Each test was performed in triplicate. Following that, a plaque assay was conducted to confirm that the plaques produced were not due to bacteriocin or any other effects. The phage stock was serially diluted to $10^{2} \mathrm{PFU} / \mathrm{mL}$ and the presence of the infectious phage was screened using the standard agar layer method [28, 29].

\section{Genome Extraction}

The DNA genome was extracted from a concentrated phage stock $\left(10^{10} \mathrm{PFU} / \mathrm{mL}\right)$ following the modified phenol-chloroform extraction protocols described by Ausubel et al. [36]. The extracted DNA was then precipitated with ice-cold $100 \%$ ethanol supplemented with sodium acetate ( $\mathrm{pH} 4.8)$.

\section{Genome Sequencing and Assembly}

The whole phage genome was sequenced using the Illumina Miseq platform (MiSeq reagent nano kit v2, 300 cycles, MiSeq 

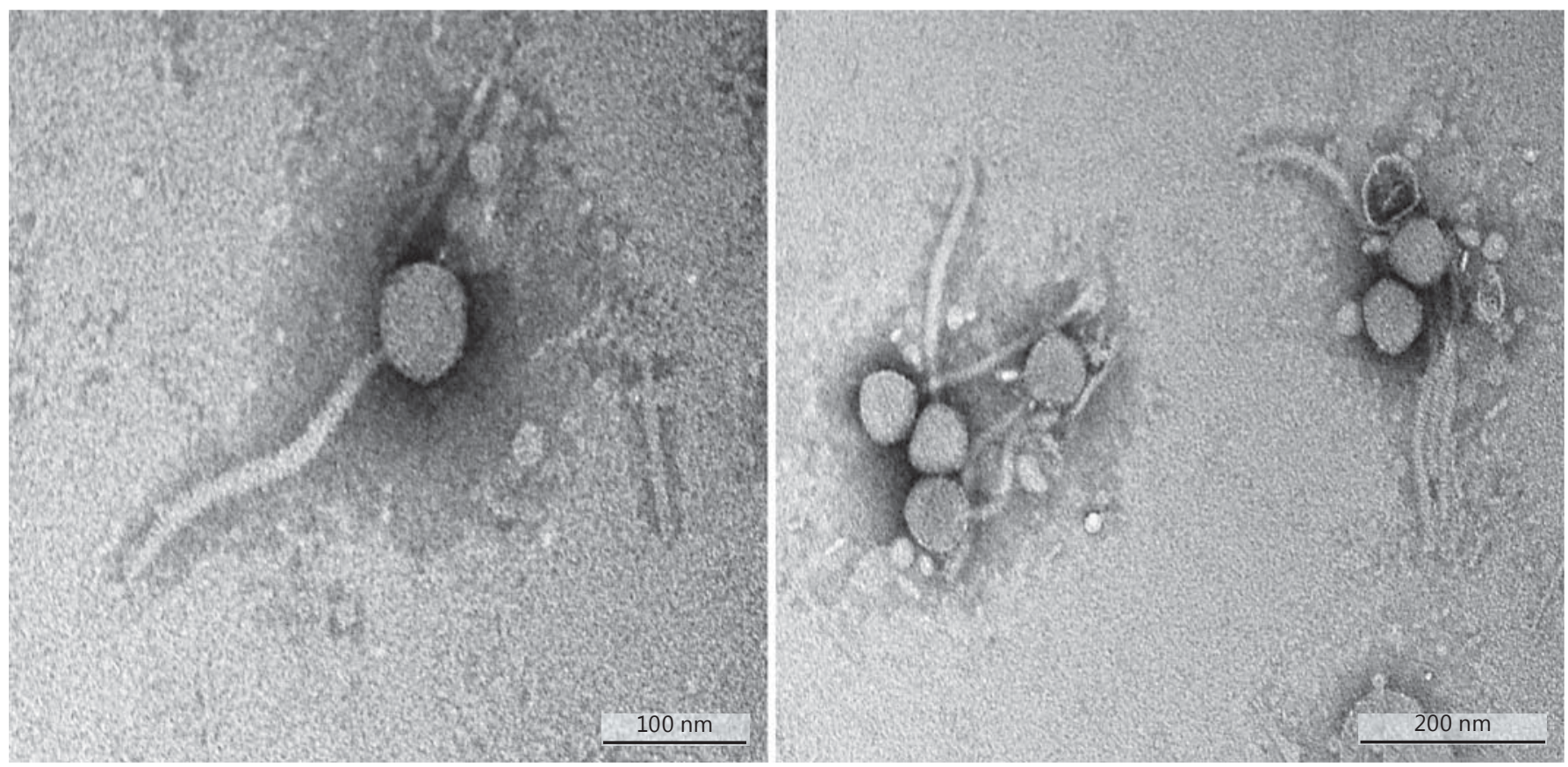

Fig. 1. Electron micrographs of phage pPM_01 after being negatively stained with $2 \%$ methylamine tungstate.

Desktop Sequencer) [37]. An amount of $1 \mu \mathrm{g}$ of the purified phage DNA was used. The sequencing DNA library was prepared using a Nextera XT DNA sample preparation kit (Illumina, USA) following the manufacturer's protocol. The genome was sequenced using $2 \times 150$ bp paired-end reads to a depth of $100 \times$ coverage. The base pair reads were then de novo assembled using into a single sequence CLC Genomics Workbench (Qiagen) [38]. The DNA size and GC content of the isolated phage were determined. The presence of tRNA was scanned through tRNAscan-SE Search (tRNAscan v1.3) [39].

\section{ORF Prediction and Genome Annotation}

A whole genome sequence of phage pPM_01 was compared using BLAST search (blastn) against the National Center for Biotechnology Information (NCBI) GenBank database to find the sequence homology [40]. Open reading frames (ORF) were automatically identified employing Rapid Annotation using Subsystem Technology (RAST) (http://rast.nmpdr.org/) [41] and Geneious software (Biomatters Limited). Additional protein homology searches of nucleotide sequences and manual annotation of putative translated ORF products were carried out using blastx at NCBI (http://blast.ncbi.nlm.nih.gov) against a nonredundant protein sequence database (E value cut-off $<10^{-4}$ ) [3] to compare the homologies with known protein sequences. Finally, the genome annotation was mapped using Geneious software.

\section{SDS-PAGE Analysis}

The structural proteins of phage pPM_01 were analyzed using SDS-PAGE [36]. The standard protocols for the SDS-PAGE analysis were modified from the gel method of Laemmli [42]. Polyacrylamide gel electrophoresis was cast as $10 \%$ of the resolving gel and topped with $4 \%$ of the stacking gel. The standard protocol for using the electrophoresis apparatus was followed as described in the Mini-PROTEAN ${ }^{\circledR}$ Tetra Cell (Bio-Rad, USA) manual. The phage particles were concentrated using ultracentrifugation (Beckman Coulter) at $100000 \mathrm{~g}$ and $4^{\circ} \mathrm{C}$ for $2 \mathrm{~h}$ and the pellet was resuspended in $200 \mu \mathrm{L}$ of LB. Fifteen microliters of the phage sample was solubilized with $5 \mu \mathrm{L}$ of $4 \times$ sample loading buffer and the denatured samples were cooled on ice for several minutes. Electrophoresis was carried out as in the protocol and the gel was stained with Coomassie brilliant blue (Amresco, USA).

\section{Nucleotide Sequence Accession Number}

The full phage pPM_01 DNA genome sequence has been deposited in the NCBI GenBank database under the accession number KP063118.

\section{Results}

\section{Electron Microscopy}

TEM revealed phage pPM_01 as a tailed phage in the family of Siphoviridae based on its icosahedral head diameter $(63 \mathrm{~nm})$ and its noncontractile tail length and diameter (263 and $11 \mathrm{~nm}$, respectively; Fig. 1). The head size is relatively similar to the general size of Siphoviridae phages, which possesses an icosahedral head size ranging from 55 to $60 \mathrm{~nm}$ [43]. 


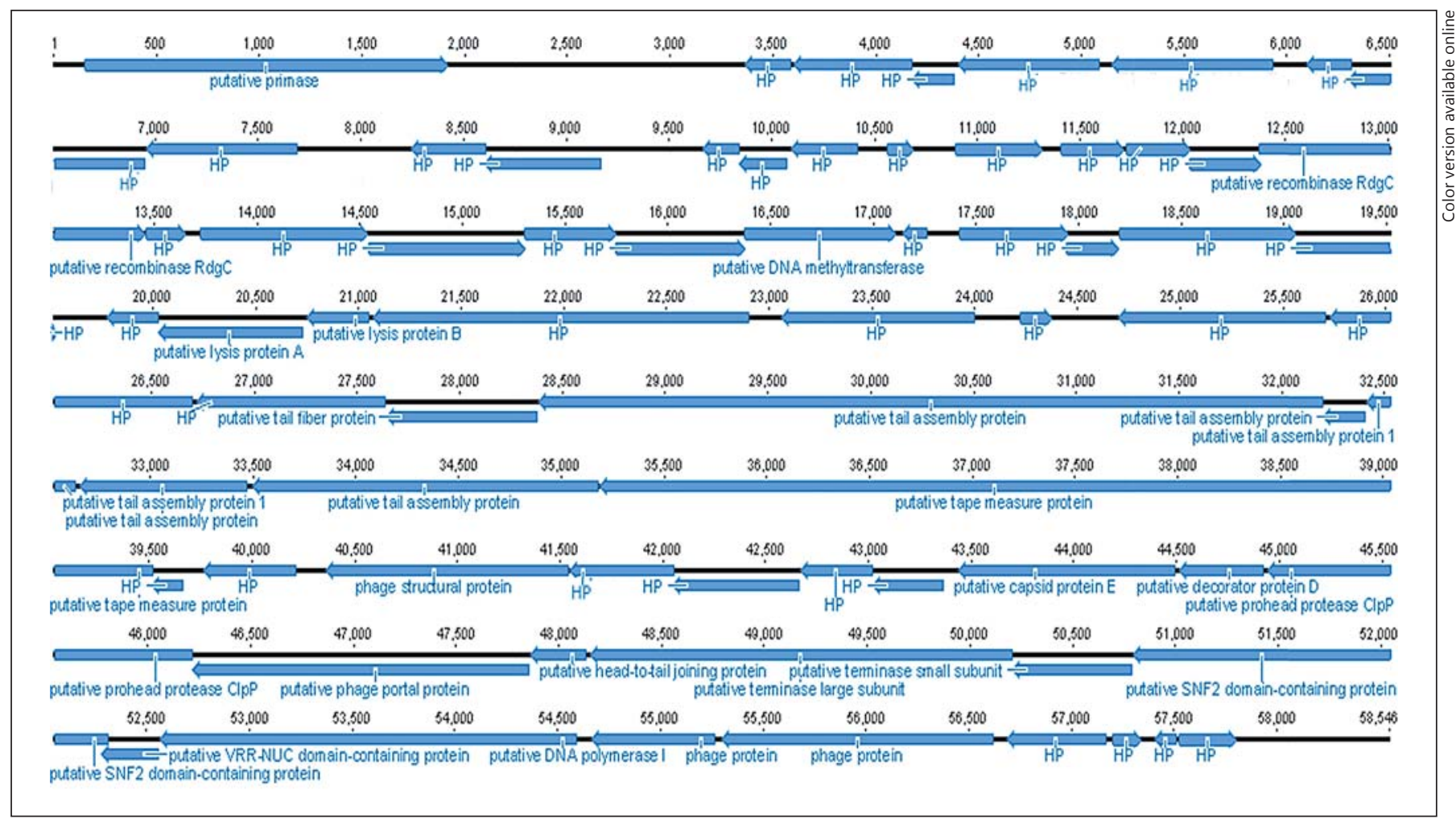

Fig. 2. Map of phage pPM_01 genome. The direction of the arrow reflects the transcription orientation. HP, hypothetical protein. The scale unit is base pairs and the scale bars mark the genome positions at 500-bp intervals.

\section{Host Range Analysis}

The host range of phage pPM_01 was analyzed against several bacteria (Table 1) that have the potential to cause UTI. In this assay, the phage was lytic to P. mirabilis only as no lytic activity was observed on the other tested bacteria. Single plaques were observed after the plaque assay indicated that the clear zones were produced by infectious phages and not due to bacteriocin or other effects. The host range analysis investigated the virulence spectrum limitation of the phage towards different bacteria, which must be understood in order to enable successful in vivo testing [44]. Narrow host range may be undesirable, but phage pPM_01 can be applied as part of the phage cocktails in phage therapy due to its efficacy in restraining the P. mirabilis host.

\section{Genomic Analysis}

The paired-end reads are assembled into a complete genome sequence of 58,546 bp in length (Fig. 2) with a GC content of $46.9 \%$. The shortest ORF encodes 38 amino acids while the highest encodes 1,446 amino acids. The

P. mirabilis Phage pPM_01 predominant initiation codons are ATG followed by 6 ORF beginning with TTG and 5 with GTG. Meanwhile, UAA (42 ORF) and UGA (17 ORF) are the predominant termination codons. A description of the predicted amino acid sequences is presented in Table 2, with no tRNA genes detected. When the complete genome sequence of phage pPM_01 was compared with those of the other phages for which data are available in the NCBI GenBank, it was found that phage pPM_01 shares some degree of similarity with Enterobacter phage Enc34 (Genbank accession No. JQ340774.1) and Enterobacteria phage Chi (JX094499). The Enterobacter phage Enc34 genome consists of 60,364 bp with a GC content of $51.07 \%$, which is 1,818 bp larger than the phage pPM_01 genome [45].

\section{Prediction of the Gene Function}

The assembled complete genome indicates the presence of 70 potential ORF (Fig. 2). Based on the ORF analysis, $23(32.9 \%)$ of the 70 putative ORF were assigned functions according to their known homologous sequences. The predicted ORF were classified into the fol-

Intervirology 2016;59:243-253 DOI: $10.1159 / 000468987$ 
Table 2. Annotated open reading frames of phage pPM_01

\begin{tabular}{|c|c|c|c|c|c|c|c|}
\hline $\begin{array}{l}\text { Open } \\
\text { reading } \\
\text { frame }\end{array}$ & Strand & Start & Stop & $\begin{array}{l}\text { Size, amino } \\
\text { acids }\end{array}$ & Predicted function & $\begin{array}{l}\text { E value/aa } \\
\text { identity, \% }\end{array}$ & GenBank Accession No. \\
\hline 1 & + & 154 & 1,920 & 589 & $\begin{array}{l}\text { putative primase } \\
\text { (Salmonella phage iEPS5) }\end{array}$ & $3 \mathrm{E}-97 / 35$ & YP_008240303.1 \\
\hline 2 & - & 3,590 & 3,366 & 75 & hypothetical protein & $-1-$ & - \\
\hline 3 & - & 4,180 & 3,602 & 193 & $\begin{array}{l}\text { hypothetical protein } \\
\text { (Providencia alcalifaciens F90-2004) }\end{array}$ & $3 \mathrm{E}-16 / 40$ & ETT05661.1 \\
\hline 4 & - & 4,389 & 4,177 & 71 & hypothetical protein & $-1-$ & - \\
\hline 5 & - & 5,092 & 4,403 & 230 & hypothetical protein & $-1-$ & - \\
\hline 6 & - & 5,936 & 5,145 & 264 & hypothetical protein & $-1-$ & - \\
\hline 7 & - & 6,319 & 6,098 & 74 & hypothetical protein & $-1-$ & - \\
\hline 8 & - & 6,953 & 6,303 & 217 & $\begin{array}{l}\text { hypothetical protein } \\
\text { (Listeria phage LP-114) }\end{array}$ & $2 \mathrm{E}-70 / 54$ & YP_009045137.1 \\
\hline 9 & - & 7,697 & 6,957 & 247 & hypothetical protein & $-1-$ & - \\
\hline 10 & - & 8,611 & 8,246 & 122 & hypothetical protein & $-1-$ & - \\
\hline 11 & - & 9,173 & 8,604 & 190 & hypothetical protein & $-1-$ & - \\
\hline 12 & - & 9,850 & 9,662 & 63 & hypothetical protein & $-1-$ & - \\
\hline 13 & - & 10,082 & 9,840 & 81 & hypothetical protein & $-1-$ & - \\
\hline 14 & - & 10,420 & 10,094 & 109 & hypothetical protein & $-1-$ & - \\
\hline$\overline{15}$ & + & 10,565 & 10,693 & 43 & hypothetical protein & $-1-$ & - \\
\hline 16 & + & 10,892 & 11,323 & 144 & $\begin{array}{l}\text { hypothetical protein } \\
\text { (Enterobacter phage Enc34) }\end{array}$ & $1 \mathrm{E}-6 / 31$ & YP_007007063.1 \\
\hline 17 & + & 11,405 & 11,716 & 104 & hypothetical protein & $-1-$ & - \\
\hline 18 & + & 11,722 & 12,042 & 107 & $\begin{array}{l}\text { hypothetical protein } \\
\text { (Salmonella phage FSL SP-124) }\end{array}$ & $5 \mathrm{E}-5 / 29$ & AGF87997.1 \\
\hline 19 & + & 12,036 & 12,383 & 116 & hypothetical protein & $-1-$ & - \\
\hline 20 & + & 12,370 & 13,458 & 363 & $\begin{array}{l}\text { putative recombinase } \mathrm{RdgC} \\
\text { (Pseudomonas) }\end{array}$ & $4 \mathrm{E}-13 / 30$ & WP_003442690.1 \\
\hline 21 & + & 13,461 & 13,661 & 67 & $\begin{array}{l}\text { hypothetical protein } \\
\text { (Enterobacter phage Enc34) }\end{array}$ & $1 \mathrm{E}-11 / 57$ & YP_007007058.1 \\
\hline 22 & + & 13,728 & 14,546 & 273 & hypothetical protein & $-1-$ & - \\
\hline 23 & + & 14,543 & 15,310 & 256 & hypothetical protein & $-1-$ & - \\
\hline 24 & + & 15,307 & 15,753 & 149 & hypothetical protein & $-1-$ & - \\
\hline 25 & + & 15,746 & 16,378 & 211 & hypothetical protein & $-1-$ & - \\
\hline 26 & + & 16,378 & 17,115 & 246 & $\begin{array}{l}\text { putative DNA methyltransferase } \\
\text { (Providencia phage Redjac) }\end{array}$ & $1 \mathrm{E}-72 / 49$ & YP_006905998.1 \\
\hline 27 & - & 17,267 & 17,142 & 42 & hypothetical protein & $-1-$ & - \\
\hline 28 & + & 17,417 & 17,950 & 178 & hypothetical protein & $-1-$ & - \\
\hline 29 & + & 17,943 & 18,194 & 84 & hypothetical protein & $-1-$ & - \\
\hline 30 & + & 18,196 & 19,065 & 290 & hypothetical protein & $-1-$ & - \\
\hline 31 & + & 19,062 & 19,526 & 155 & $\begin{array}{l}\text { hypothetical protein } \\
\text { (Salmonella phage iEPS5) }\end{array}$ & $2 \mathrm{E}-22 / 42$ & YP_008240264.1 \\
\hline 32 & - & 20,030 & 19,776 & 85 & hypothetical protein & $-1-$ & - \\
\hline 33 & - & 20,734 & 20,030 & 235 & $\begin{array}{l}\text { putative lysis protein A } \\
\text { (Salmonella phage FSL SP-099) }\end{array}$ & $1 \mathrm{E}-81 / 57$ & AGF89680.1 \\
\hline 34 & - & 21,059 & 20,745 & 105 & $\begin{array}{l}\text { putative lysis protein B } \\
\text { (Salmonella phage iEPS5) }\end{array}$ & $9 \mathrm{E}-13 / 33$ & YP_008240268.1 \\
\hline 35 & - & 22,908 & 21,070 & 613 & $\begin{array}{l}\text { hypothetical protein } \\
\text { (Staphylococcus phage SA1) }\end{array}$ & $1 \mathrm{E}-29 / 29$ & ACZ55502.1 \\
\hline 36 & - & 24,000 & 23,059 & 314 & hypothetical protein & $-1-$ & - \\
\hline 37 & + & 24,224 & 24,382 & 53 & hypothetical protein & $-1-$ & - \\
\hline 38 & - & 25,713 & 24,697 & 339 & $\begin{array}{l}\text { hypothetical protein } \\
\text { (Salmonella phage iEPS5) }\end{array}$ & $2 \mathrm{E}-152 / 60$ & YP_008240271.1 \\
\hline 39 & - & 26,706 & 25,726 & 327 & $\begin{array}{l}\text { hypothetical protein } \\
\text { (Enterobacteria phage Chi) }\end{array}$ & $3 \mathrm{E}-94 / 46$ & YP_008058190.1 \\
\hline
\end{tabular}


Table 2 (continued)

\begin{tabular}{|c|c|c|c|c|c|c|c|}
\hline $\begin{array}{l}\text { Open } \\
\text { reading } \\
\text { frame }\end{array}$ & Strand & Start & Stop & $\begin{array}{l}\text { Size, amino } \\
\text { acids }\end{array}$ & Predicted function & $\begin{array}{l}\text { E value/aa } \\
\text { identity, \% }\end{array}$ & GenBank Accession No. \\
\hline 40 & - & 27,640 & 26,720 & 307 & $\begin{array}{l}\text { hypothetical protein } \\
\text { (Salmonella phage FSL SP-088) }\end{array}$ & $1 \mathrm{E}-41 / 34$ & YP_008239940.1 \\
\hline$\overline{41}$ & - & 28,383 & 27,640 & 248 & $\begin{array}{l}\text { putative tail fiber protein } \\
\text { (Providencia phage Redjac) }\end{array}$ & $3 \mathrm{E}-83 / 50$ & YP_006905987.1 \\
\hline$\overline{42}$ & - & 32,207 & 28,383 & 1,275 & $\begin{array}{l}\text { putative tail assembly protein } \\
\text { (Providencia phage Redjac) }\end{array}$ & $0 / 44$ & YP_006905986.1 \\
\hline 43 & - & 32,409 & 32,200 & 70 & $\begin{array}{l}\text { putative tail assembly protein } \\
\text { (Enterobacter phage Enc34) }\end{array}$ & $4 \mathrm{E}-8 / 37$ & YP_007007028.1 \\
\hline$\overline{44}$ & - & 32,645 & 32,409 & 79 & $\begin{array}{l}\text { Putative tail assembly protein } 1 \\
\text { (Salmonella phage SPN19) }\end{array}$ & $7 \mathrm{E}-24 / 67$ & YP_006990293.1 \\
\hline$\overline{45}$ & - & 33,473 & 32,658 & 272 & $\begin{array}{l}\text { putative tail assembly protein } \\
\text { (Enterobacter phage Enc34) }\end{array}$ & $7 \mathrm{E}-100 / 55$ & YP_007007026.1 \\
\hline$\overline{46}$ & - & 35,182 & 33,494 & 563 & $\begin{array}{l}\text { putative tail assembly protein } \\
\text { (Enterobacter phage Enc34) }\end{array}$ & $2 \mathrm{E}-124 / 40$ & YP_007007025.1 \\
\hline$\overline{47}$ & - & 39,525 & 35,188 & 1,446 & $\begin{array}{l}\text { putative tape measure protein } \\
\text { (Salmonella phage FSL SP-088) }\end{array}$ & $0 / 44$ & YP_008239947.1 \\
\hline 48 & - & 39,673 & 39,515 & 53 & hypothetical protein & $-1-$ & - \\
\hline$\overline{49}$ & - & 40,218 & 39,766 & 151 & $\begin{array}{l}\text { hypothetical protein } \\
\text { (Enterobacteria phage Chi) }\end{array}$ & $6 \mathrm{E}-30 / 40$ & YP_008058180.1 \\
\hline 50 & - & 41,544 & 40,357 & 396 & $\begin{array}{l}\text { phage structural protein } \\
\text { (Enterobacter phage Enc34) }\end{array}$ & $3 \mathrm{E}-98 / 52$ & YP_007007020.1 \\
\hline 51 & - & 42,060 & 41,548 & 171 & $\begin{array}{l}\text { hypothetical protein } \\
\text { (Salmonella phage SPN19) }\end{array}$ & $2 \mathrm{E}-31 / 46$ & YP_006990300.1 \\
\hline 52 & - & 42,667 & 42,050 & 206 & $\begin{array}{l}\text { hypothetical protein } \\
\text { (Providencia phage Redjac) }\end{array}$ & $2 \mathrm{E}-66 / 56$ & YP_006906022.1 \\
\hline 53 & - & 43,023 & 42,670 & 118 & $\begin{array}{l}\text { hypothetical protein } \\
\text { (Enterobacter phage Enc34) }\end{array}$ & $4 \mathrm{E}-25 / 46$ & YP_007007017.1 \\
\hline 54 & - & 43,370 & 43,023 & 116 & $\begin{array}{l}\text { hypothetical protein } \\
\text { (Salmonella phage FSL SP-030) }\end{array}$ & $1 \mathrm{E}-5 / 47$ & YP_008239848.1 \\
\hline 55 & - & 44,501 & 43,434 & 356 & $\begin{array}{l}\text { putative capsid protein E } \\
\text { (Salmonella phage FSL SP-030) }\end{array}$ & $7 \mathrm{E}-155 / 60$ & YP_008239847.1 \\
\hline 56 & - & 44,930 & 44,514 & 139 & $\begin{array}{l}\text { putative decorator protein D } \\
\text { (Salmonella phage FSL SP-030) }\end{array}$ & $7 \mathrm{E}-24 / 42$ & YP_008239846.1 \\
\hline 57 & - & 46,221 & 44,944 & 426 & $\begin{array}{l}\text { putative prohead protease ClpP } \\
\text { (Burkholderia phage BcepNazgul) }\end{array}$ & $2 \mathrm{E}-82 / 46$ & NP_918994.2 \\
\hline$\overline{58}$ & - & 47,861 & 46,218 & 548 & $\begin{array}{l}\text { putative phage portal protein, lambda } \\
\text { family (Enterobacteria phage Chi) }\end{array}$ & $0 / 60$ & YP_008058171.1 \\
\hline 59 & - & 48,136 & 47,861 & 92 & $\begin{array}{l}\text { putative head-to-tail joining protein } \\
\text { (Enterobacter phage Enc } 34 \text { ) }\end{array}$ & $6 \mathrm{E}-14 / 49$ & YP_007007011.1 \\
\hline 60 & - & 50,215 & 48,149 & 689 & $\begin{array}{l}\text { putative terminase large subunit } \\
\text { (Enterobacteria phage Chi) }\end{array}$ & $0 / 62$ & YP_008058169.1 \\
\hline 61 & - & 50,792 & 50,208 & 195 & $\begin{array}{l}\text { putative terminase small subunit } \\
\text { (Enterobacter phage Enc34) }\end{array}$ & $2 \mathrm{E}-67 / 57$ & YP_007007009.1 \\
\hline 62 & - & 52,318 & 50,795 & 508 & $\begin{array}{l}\text { putative SNF2 domain-containing } \\
\text { protein (Salmonella phage SPN19) }\end{array}$ & $1 \mathrm{E}-140 / 46$ & YP_006990311.1 \\
\hline 63 & - & 52,565 & 52,278 & 96 & $\begin{array}{l}\text { putative VRR-NUC domain- } \\
\text { containing protein (Salmonella } \\
\text { phage SPN19) }\end{array}$ & $6 \mathrm{E}-28 / 58$ & YP_006990312.1 \\
\hline 64 & - & 54,598 & 52,565 & 678 & $\begin{array}{l}\text { putative DNA polymerase I } \\
\text { (Providencia phage Redjac) }\end{array}$ & $0 / 56$ & YP_006906013.1 \\
\hline 65 & - & 55,268 & 54,663 & 202 & $\begin{array}{l}\text { hypothetical protein } \\
\text { (Salmonella phage FSL SP-099) }\end{array}$ & $4 \mathrm{E}-40 / 48$ & AGF89722.1 \\
\hline 66 & - & 56,628 & 55,300 & 443 & $\begin{array}{l}\text { hypothetical protein } \\
\text { (Salmonella phage FSL SP-124) }\end{array}$ & $5 \mathrm{E}-103 / 39$ & AGF88050.1 \\
\hline
\end{tabular}


Table 2 (continued)

\begin{tabular}{lllllll}
\hline $\begin{array}{l}\text { Open } \\
\text { reading } \\
\text { frame }\end{array}$ & Strand & Start & Stop & $\begin{array}{l}\text { Size, amino } \\
\text { acids }\end{array}$ & Predicted function & $\begin{array}{l}\text { E value/aa } \\
\text { identity, } \%\end{array}$ \\
\hline 67 & - & 57,171 & 56,689 & 161 & hypothetical protein & $-/-$ \\
\hline 68 & + & 57,201 & 57,344 & 48 & hypothetical protein & $-/-$ \\
\hline 69 & - & 57,517 & 57,404 & 38 & hypothetical protein & $-/-$ \\
\hline 70 & + & 57,524 & 57,808 & 95 & hypothetical protein & - \\
\hline
\end{tabular}

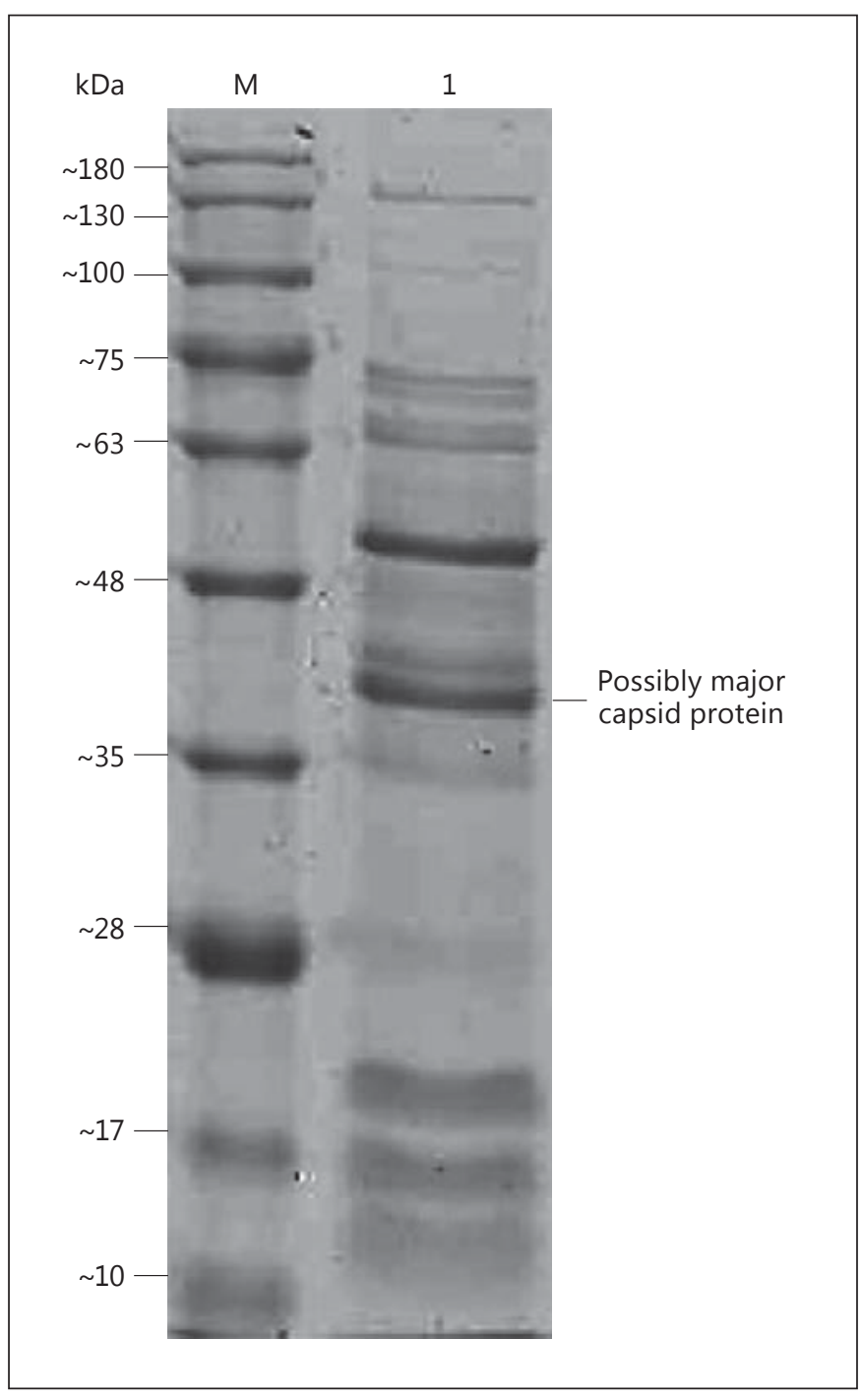

Fig. 3. SDS-PAGE analysis of phage pPM_01 structural proteins on $10 \%$ gel staining with Coomassie brilliant blue. M, standard marker of molecular weight $(\mathrm{kDa})$. Lane 1: phage pPM_01 protein profile. lowing 6 functional groups: tail structural components and assembly, head structural components and assembly, DNA packaging, host lysis, DNA replication and gene expression modulation, and DNA recombination/modification. Seventeen $(24.3 \%)$ of them were putative proteins, which matched the hypothetical proteins in the nonredundant and phage protein databases of NCBI. Thirty (42.9\%) of the predicted ORF were lacking in identity to any known proteins, yet they were assigned to the hypothetical proteins.

The terminase subunits (ORF60 and ORF61) of phage pPM_01 are putative proteins that are involved in DNA packaging. Phage pPM_01 ORF60 encodes 689 amino acids with $62 \%$ similarities to the known large terminase subunit of phage chi, which implies a similar function in DNA packaging. The terminase enzymes producing the phage genome ends are relatively varied, but the genes are conserved among tailed phages. The presence of terminase_GpA superfamily in ORF60 may be involved in the late stages of DNA packaging as in $\lambda$ phage [46]. To study the genome end of phage PPM_01, an additional phylogenetic analysis was conducted based on the terminase large subunit [47]. This comparative analysis suggested that the end of the genome for phage pPM_01 likely belongs to the " $\lambda$-like 5 '-extended COS ends" group. Phages belonging to this group usually have linear DNA genomes that circularize once released inside the infected host.

Based on the amino acid sequence analysis (Table 2), a clear lifestyle prediction for phage pPM_01 is likely impossible, probably due to the very low amino acid sequence identities of the predicted ORF in phage pPM_01 to those of other known phages. Most of the annotated genes encode unknown proteins, indicating that further genomic study of phage PPM_01 is required to elucidate its infection mechanism, the stage of the replication cycle, the presence of possible virulence genes, and much more. 


\section{SDS-PAGE Analysis}

The predominant polypeptide band is generally proposed as a major capsid protein due to the high copy number of capsid proteins [48]. Lane 1 of the gel (Fig. 3) clearly showed distinct protein bands with a molecular weight ranging approximately from 11 to $130 \mathrm{kDa}$. Two predominant polypeptide bands were observed approximately between $35-48 \mathrm{kDa}$ and $48-63 \mathrm{kDa}$. Mostly, the detected molecular masses correlated well to the theoretical molecular size deduced from the corresponding ORF. Thus, the theoretical molecular size of phage pPM_01 further suggests that the protein band with a weight from 35 to $48 \mathrm{kDa}$ is the capsid protein E of phage pPM_01. Besides that, the estimated molecular weights of the phage pPM_01 capsid protein E (ORF 55) and its homolog in Salmonella phage FSL SP-030 are almost the same, i.e., $42.6 \mathrm{kDa}$ and $39.9 \mathrm{kDa}$, respectively [49].

\section{Discussion}

Phage pPM_01 is the first lytic phage specific to host $P$. mirabilis whose complete genomic sequence has been determined. Phage pPM_01 genes are organized tightly in the genome as some of the stop codons are overlapped to the start codons of the following gene (Fig. 2) [50]. Significant portions of the ORF genes are located on the left arm of the genome and the encoding proteins, which means that no functional assignment could be made at the time of reporting.

The gene order revealed that most of the genes in phage PPM_01 were found on the reverse strand [51]. S schematic representation of the phage pPM_01 genome showed a very high similarity with the genome organization of phage [52]. The exception was the primase protein located at the right arm end of the phage iEPS5 genome instead of the left arm end, as in the pPM_01 genome. Four of the functional groups of the pPM_01 genome classified as the tail structure components and assembly, head structural and assembly, DNA packaging, and host lysis were on the reverse strand. Likewise, all of the genes encoded for the DNA replication and gene expression modulation were also found on the reverse strand, except for the primase protein located on the forward strand. Meanwhile, the genes encoded for DNA recombination/ modification were also on the forward strand.

Based on genomic analyses, no genomic markers demonstrating a temperate lifestyle were found in the phage pPM_01 genome. This revealed phage pPM_01 as an appropriate candidate for phage therapy application in

P. mirabilis Phage pPM_01 treating diseases caused by $P$. mirabilis. In fact, in vitro study of phage pPM_01 showed that pPM_01 was highly lytic and virulent against $P$. mirabilis (data not shown). The presence of putative lysis proteins A and B (ORF 33 and ORF 34) would indicate that phage PPM_01 is a lytic phage [53]. A previous study by O’Flynn et al. [54] reported that an isolated phage of the Myoviridae family had acquired an eaeA virulence factor from the host genome. In contrast, neither virulence factors nor potentially known toxins were identified in the phage pPM_01 genome, thus indicating that phage pPM_01 might be safe for phage therapy. The phage pPM_01 genome was also unlikely to transfer genes to other bacteria since no prophage characteristics were found. Avoiding temperate phages for phage therapy is necessary since most prophages would integrate into the host genome and somehow acquire virulence genes upon excision from the host genome [54-56].

The phage pPM_01 genome organization was successfully constructed and analysis of the annotated genes provided insight into its genetic identity and relations with other phages. The data leaned toward identifying phage pPM_01 as a new addition to the phage database, specifically phages infecting $P$. mirabilis. In addition to the expected genes such as capsid and tail, other genes commonly present in a phage were annotated as well. The presence of putative proteins and uncharacterized proteins was typically anticipated for a new phage not previously isolated and characterized. Additionally, the absence of virulence and toxin genes in the genome of phage pPM_01 provides hope for this phage to be further developed for phage therapy.

\section{Acknowledgements}

I.A.W. was supported by MyBrain15 Sponsorship from the Ministry of Higher Education of Malaysia. Part of this research was supported by an ERGS grant from Ministry of Higher Education Malaysia (203/PBIOLOGI/6730105) as well as a Mangrove grant (1001/PCCB/870009) from the Centre for Chemical Biology, University Sains Malaysia. We would like to acknowledge the School of Biological Sciences, Universiti Sains Malaysia, for the technical support and the Electron Microscopy Unit for producing the electron micrographs.

\section{Disclosure Statement}

The authors have no conflicts of interest to declare. 


\section{References}

1 Kutateladze M, Adamia R: Bacteriophages as potential new therapeutics to replace or supplement antibiotics. Trends Biotechnol 2010; 28:591-595.

2 Dorval Courchesne NM, Parisien A, Lan CQ: Production and application of bacteriophage and bacteriophage-encoded lysins. Recent Pat Biotechnol 2009;3:37-45.

3 Ahern SJ, Das M, Bhowmick TS, Young R, Gonzalez CF: Characterization of novel virulent broad-host-range phages of Xylella fastidiosa and Xanthomonas. J Bacteriol 2014; 196:459-471.

4 Breitbart M, Rohwer F: Here a virus, there a virus, everywhere the same virus? Trends $\mathrm{Mi}-$ crobiol 2005; 13:278-284.

5 Matsuzaki S, Rashel M, Uchiyama J, Sakurai S, Ujihara T, Kuroda M, Ikeuchi M, Tani T, Fujieda $M$, Wakiguchi $H$, Imai S: Bacteriophage therapy: a revitalized therapy against bacterial infectious diseases. I Infect Chemother 2005;11:211-219.

6 Kutter E, De Vos D, Gvasalia G, Alavidze Z, Gogokhia L, Kuhl S, Abedon ST: Phage therapy in clinical practice: treatment of human infections. Curr Pharm Biotechnol 2010;11: 69-86.

7 Clark JR, March JB: Bacteriophages and biotechnology: Vaccines, gene therapy and antibacterials. Trends Biotechnol 2006;24:212218.

8 Ackermann HW: Bacteriophage taxonomy. Microbiol Aust 2011;32:90-94.

9 Gill JJ, Hyman P: Phage choice, isolation, and preparation for phage therapy. Curr Pharm Biotechnol 2010;11:2-14.

10 Motlagh AM, Bhattacharjee AS, Goel R: Biofilm control with natural and geneticallymodified phages. World J Microbiol Biotechnol 2016;32:1-10.

11 Brovko LY, Anany H, Griffiths MW: Chapter six - bacteriophages for detection and control of bacterial pathogens in food and food-processing environment; in Jeyakumar $\mathrm{H}$ (ed) Advances in Food and Nutrition Research. Cambridge, Academic Press, 2012, vol 67, pp 241-288.

12 Madigan MT, Martinko JM, Dunlap PV, Clark DP: Brock Biology of Microorganisms, ed 12. London, Pearson, 2008, pp 65-73.

13 Groisman EA, Casadesús J: The origin and evolution of human pathogens. Mol Microbiol 2005;56:1-7.

14 Goldman E, Green LH: Practical Handbook of Microbiology. Boca Raton, CRC Press, 2015.

15 Price P, Price P, Frey KB: Microbiology for Surgical Technologists. Albany, Thomson/ Delmar Learning, 2003.

16 Carson L, Gorman SP, Gilmore BF: The use of lytic bacteriophages in the prevention and eradication of biofilms of Proteus mirabilis and Escherichia coli. FEMS Immunol Med Microbiol 2010;59:447-455.
17 Gravitz L: Turning a new phage. Nat Med 2012;18:1318-1320.

18 Parasion S, Kwiatek M, Gryko R, Mizak L, Malm A: Bacteriophages as an alternative strategy for fighting biofilm development. Pol J Microbiol 2014;63:137-145.

19 Manos J, Belas R: The genera Proteus, Providencia, and Morganella; in Dworkin M Falkow S, Rosenberg E, Schleifer K-H, Stackebrandt E (eds): The Prokaryotes. New York, Springer, 2006, pp 245-269.

20 Chen C-Y, Chen Y-H, Lu P-L, Lin W-R, Chen T-C, Lin C-Y: Proteus mirabilis urinary tract infection and bacteremia: risk factors, clinical presentation, and outcomes. J Microbiol Immunol Infect 2012;45:228-236.

21 Lee JBL, Neild GH: Urinary tract infection. Medicine 2007;35:423-428.

22 Natarajan V: Urinary tract infection. Surgery 2008;26:193-196.

23 Sheerin NS: Urinary tract infection. Medicine 2011:39:384-389.

24 Srivastava R, Vasudev A: Urinary tract infections: current management. Apollo Med 2011;8:270-275.

25 Nagano N, Shibata N, Saitou Y, Nagano Y, Arakawa Y: Nosocomial outbreak of infections by Proteus mirabilis that produces extended-spectrum CTX-M- 2 type $\beta$-lactamase. J Clin Microbiol 2003;41:5530-5536.

26 Torres-Barceló C, Hochberg ME: Evolutionary rationale for phages as complements of antibiotics. Trends Microbiol 2016;24:249256

27 Domingo-Calap P, Georgel P, Bahram S: Back to the future: bacteriophages as promising therapeutic tools. HLA 2016;87:133-140.

28 Adams M: Bacteriophages. New York, Interscience, 1959.

29 Carey-Smith GV, Billington C, Cornelius AJ, Hudson JA, Heinemann JA: Isolation and characterization of bacteriophages infecting Salmonella spp. FEMS Microbiol Lett 2006; 258:182-186.

30 Sillankorva S, Neubauer P, Azeredo J: Isolation and characterization of a T7-like lytic phage for Pseudomonas fluorescens. BMC Biotechnol 2008;8:80.

31 Sambrook JF, Russell DW: Molecular Cloning: a Laboratory Manual. New York, Cold Spring Harbor Laboratory Press, 2001, vol 3.

32 Chekabab SM, Jubelin G, Dozois CM, Harel J: Phob activates Escherichia coli O157:H7 virulence factors in response to inorganic phosphate limitation. PLoS One 2014;9:e94285.

33 Bradley D, Douglas C, Peschon J: Flagellaspecific bacteriophages of Agrobacterium tumefaciens: demonstration of virulence of nonmotile mutants. Can J Microbiol 1984;30: 676-681.

34 Brenner S, Horne R: A negative staining method for high resolution electron microscopy of viruses. Biochim Biophys Acta 1959; 34:103-110.
35 Jun JW, Kim JH, Shin SP, Han JE, Chai JY, Park SC: Characterization and complete genome sequence of the Shigella bacteriophage pSf-1. Res Microbiol 2013;164:979-986.

36 Ausubel FM, Brent R, Kingston RE, Moore DD, Seidman JG, Smith JA, Struhl K: Short Protocols in Molecular Biology, ed 4. Hoboken, Wiley, 1999.

37 Denes T, Vongkamjan K, Ackermann H-W, Moreno Switt AI, Wiedmann M, den Bakker HC: Comparative genomic and morphological analyses of Listeria phages isolated from farm environments. Appl Environ Microbiol 2014;80:4616-4625.

38 Sajben-Nagy E, Maróti G, Kredics L, Horváth B, Párducz Á, Vágvölgyi C, Manczinger L: Isolation of new Pseudomonas tolaasii bacteriophages and genomic investigation of the lytic phage BF7. FEMS Microbiol Lett 2012; 332:162-169.

39 Lowe T, Eddy S: tRNAscan-se: a program for improved detection of transfer RNA genes in genomic sequence. Nucleic Acids Res 1997; 25:955-964.

40 Altschul SF, Gish W, Miller W, Myers EW, Lipman DJ: Basic local alignment search tool. J Mol Biol 1990;215:403-410.

41 Aziz R, Bartels D, Best A, DeJongh M, Disz T, Edwards R, Formsma K, Gerdes S, Glass E, Kubal M, Meyer F, Olsen G, Olson R, Osterman A, Overbeek R, McNeil L, Paarmann D, Paczian T, Parrello B, Pusch G, Reich C, Stevens $R$, Vassieva O, Vonstein $\mathrm{V}$, Wilke A, Zagnitko O: The RAST server: rapid annotations using subsystems technology. BMC Genomics 2008;9:75.

42 Laemmli UK: Cleavage of structural proteins during the assembly of the head of bacteriophage T4. Nature 1970;227:680-686.

43 Petrovski S, Dyson ZA, Seviour RJ, Tillett D: Small but sufficient: the Rhodococcus phage RRH1 has the smallest known Siphoviridae genome at 14.2 kilobases. J Virol 2012;86: 358-363.

$44 \mathrm{Lu}$ TK, Koeris MS: The next generation of bacteriophage therapy. Curr Opin Microbiol 2011;14:524-531.

45 Kazaks A, Dislers A, Lipowsky G, Nikolajeva V, Tars K: Complete genome sequence of the Enterobacter cancerogenus bacteriophage Enc34. J Virol 2012;86:11403-11404.

46 Duffy C, Feiss M: The large subunit of bacteriophage lambda's terminase plays a role in DNA translocation and packaging termination. J Mol Biol 2002;316:547-561.

47 Casjens SR, Gilcrease EB: Determining DNA packaging strategy by analysis of the termini of the chromosomes in tailed-bacteriophage virions; in Clokie MRJ, Kropinski AM (eds): Bacteriophages: Methods and Protocols. Totowa, Humana Press, 2009, vol 2, pp 91111. 
48 Kwiatek M, Parasion S, Mizak L, Gryko R, Bartoszcze M, Kocik J: Characterization of a bacteriophage, isolated from a cow with mastitis, that is lytic against Staphylococcus aureus strains. Arch Virol 2012;157:225-234.

49 Moreno Switt A, Orsi R, den Bakker H, Vongkamjan K, Altier C, Wiedmann M: Genomic characterization provides new insight into Salmonella phage diversity. BMC Genom 2013;14:481.

50 Dobbins AT, George M, Basham DA, Ford ME, Houtz JM, Pedulla ML, Lawrence JG,
Hatfull GF, Hendrix RW: Complete genomic sequence of the virulent Salmonella bacteriophage SP6. J Bacteriol 2004;186:1933-1944.

51 Roberts MD, Martin NL, Kropinski AM: The genome and proteome of coliphage T1. Virology 2004;318:245-266.

52 Choi Y, Shin H, Lee J-H, Ryu S: Identification and characterization of a novel flagellum-dependent Salmonella-infecting bacteriophage, iEPS5. Appl Environ Microbiol 2013;79:4829-4837.

53 Gan H, Sieo C, Tang S, Omar A, Ho Y: The complete genome sequence of EC1-UPM, a novel N4-like bacteriophage that infects Escherichia coli O78:K80. Virol J 2013;10:1-8.

54 O’Flynn G, Ross RP, Fitzgerald GF, Coffey A: Evaluation of a cocktail of three bacteriophages for biocontrol of Escherichia coli O157:H7. Appl Environ Microbiol 2004;70:3417-3424.

55 Skurnik M, Strauch E: Phage therapy: facts and fiction. Int J Med Microbiol 2006;296:514.

56 Sulakvelidze A, Alavidze Z, Morris JG: Bacteriophage therapy. Antimicrob Agents Chemother 2001;45:649-659. 